\title{
ANALISIS PENGARUH KOMITMEN AFEKTIF, KOMITMEN BERKELANJUTAN DAN KOMITMEN NORMATIF TERHADAP KINERJA KARYAWAN PADA PT RADIO NEBULA NADA DI KOTA PALU
}

\author{
RAZIYAM DWI PATHAN \\ SYAHIR NATSIR \\ HARNIDA WAHYUNI ADDA \\ Jurusan Manajemen, Fakultas Ekonomi, Universitas Tadulako \\ Email : raziyamdwipathan@gmail.com
}

\begin{abstract}
The purpose of this study is to determine and analyze the influence of affective commitment variable (X1), continuous Commitment (X2), and Normative commitment (X3) at PT. Radio Nebula Nada in Palu City. Hypothesis test used has significance level of $\alpha=0.05$ and for the reliability test using cronbach alpha coefficient values with the limit value coefficient of $\alpha=0.60$. The results of multiple linear regression analysis show that the variables of affective commitment (XI) and the continous commitment (X2), normative commitment (X3) simultaneously have positive and significant influence on the performance of employees at PT. Radio Nebula Nada in Palu with the adjusted Rsquare of $32.6 \%$. Partially, with standard $\alpha=0.05, X 1, X 2$, and X3 partially have significant influence on $Y$ with sig. value of $0.016,0.086$, and 0.015 , respectively. The results show that correlation coefficient of 0.627, means that affective commitment, continuous commitment, and normative commitment have strong relationship with the employee's performance of $62.7 \%$.
\end{abstract}

Keywords: affective commitment, sustainable commitment, normative commitment and employee performance PT. Radio Nebula Nada

\section{Abstrak}

Tujuan penelitian ini adalah untuk mengetahui dan menganalisis pengaruh variabel komitmen afektif (X1), Komitmen Berkelanjutan (X2), dan Komitmen Normatif (X3) pada PT Radio Nebula Nada di kota Palu. Uji hipotesis yang digunakan mempunyai taraf signifikansi $\alpha=0,05$ dan untuk uji reliabilitas menggunakan nilai koefisien croanbach alpha dengan nilai batas koefisien $\alpha=0,60$ Berdasarkan hasil analisis regresi linear berganda didapatkan bahwa variabel komitmen afektif (X1) dan komitmen berkelanjutan (X2), komitmen Normatif (X3) secara simultan berpengaruh signifikan positif terhadap kinerja karyawan pada PT Radio Nebula Nada di Kota Palu. Dengan Adjusted Rsquare sebesar 32,6\%. Secara parsial dengan standar $\alpha=0,05$ diperoleh hasil penelitian X1, X2, dan X3 berpengaruh signifikan terhadap Y dengan nilai sig masing - masing sebesar 0,016, 0,086, dan 0,015 . Hasil korelasi menunjukan nilai koefisien korelasi sebesar 0,627 yang berarti variabel komitmen afektif, komitmen berkelanjutan dan komitmen normatif mempunyai hubungan yang kuat dengan kinerja karyawan sebesar 62,7\%.

Kata Kunci: Komitmen Afektif, Komitmen Berkelanjutan, Komitmen Normatif dan Kinerja Karyawan, PT Radio Nebula Nada

\section{PENDAHULUAN}

SDM mempunyai peran yang sangat besar bagi sebuah organisasi/ perusahaan. Semua kalangan harus menyadari bahwa SDM itu unsur manusia dalam perusahaan/ organisasi yang dapat memberikan keunggulan dalam organisasi. SDM yang mampu membuat tujuan, sasaran strategi, dan inovasi yang bisa diunggulkan dalam organisasi. Maka dari itu SDM atau karyawan adalah asset perusahaan yang tak ternilai diperusahaan (Mulyadi, 2015:1).

Perkembangan teknologi informasi yang telah banyak membawa perubahan dalam berbagai bidang. Berbagai macam media yang berkembang disaat ini juga memberi kemudahan pada khalayak dalam mendapatkan hiburan dan informasi yang diinginkan dengan cepat. Di antara media massa yang berkembang dengan baik dan jumlahnya telah mencapai puluhan dibanding dengan yang lain satu di antaranya di Kota Palu adalah radio. 
PT Radio Nebula Nada merupakan salah satu media radio siaran yang digarap oleh programberisi tentang informasi, baik informasi lokal maupun mancanegara dengan memadukan bisnis menghibur (entertaint) melalui dunia siaran radio (broadcast) sehingga PT Radio Nebula Nada menjadi media pilihan bagi pendengar dikalangan masyarakat Kota Palu dan PT Radio Nebula Nada adalah radio siaran swasta pertama yang mengudara di Sulawesi Tengah. Dalam rangka menghadapi persaingan dalam bidang jasa media, PT Radio Nebula Nada melakukan perubahan yaitu diharapkan karyawan dapat meningkatkan kesadaran emosional individu dan tanggung jawab pekerja. Hal ini dapat mencapai apabila karyawan PT Radio Nebula Nada memiliki komitmen yang tinggi sehingga meningkatkan kinerja karyawan dan perusahaan. Komitmen organisasi di tunjukan agar karyawan merasa senang bekerja dalam PT Radio Nebula Nada, serta merasa memiliki tanggung jawab terhadap pekerjaan.

Berdasarkan latar belakang dan identifikasi masalah tersebut, maka penulisperlu untuk melakukan penelitian dengan menggunakan judul"Analisis Pengaruh Komitmen Organisasi Terhadap Kinerja Karyawan Pada PT Radio Nebula Nada di Kota Palu", dengan tujuan:

1. Untuk mengetahui pengaruh komitmen afektif, komitmen berkelanjutan, dan komitmen normatif secara simultan berpengaruh terhadap kinerja karyawan PT Radio Nebula Nada di Kota Palu.

2. Untuk mengetahui pengaruh parsial komitmen afektif, terhadap kinerja karyawan PT Radio Nebula Nada di Kota Palu

3. Untuk mengetahui pengaruh parsial komitmen berkelanjutan terhadap kinerja karyawan PT Radio Nebula Nada di Kota Palu.

4. Untuk mengetahui pengaruh parsial komitmen normatif terhadap kinerja karyawan PT Radio Nebula Nada di Kota Palu.

\section{KAJIAN LITERATUR DAN PENGEMBANGAN HIPOTESIS Komitmen Organisasional}

Menurut kaswan (2012: 293) mengemukakan " komitmen organisasi didefinisikan sebagai sikap yang merefleksikan loyalitas karyawan pada organisasi dan proses berkelanjutan dimana anggota organisasi mengekspresikan perhatian terhadap organisasi dan keberhasilan serta kemajuan yang berkelanjutan."

\section{Dimensi Komitmen Organisasional}

Komitmen organisasi merupakan ukuran kesediaan karyawan untuk bertahan dengan sebuah perusahaan di waktu yang akan datang maka, komitmen organisasi memiliki tiga dimensi Menurut ( Parinding 2015) : komitmen afiktif, komitmen berkelanjutan dan komitmen normatif.

\section{Faktor-faktor yang Mempengaruhi Komitmen Organisasi}

Menurut Stess dan Porter dalam sopiah (2008:156) mengemukakan ada tiga faktor yang mempengaruhi komitmen seorang karyawan antara lain:

1. Kepercayaan dan penerimaan yang kuat atas tujuan dan nilai-nilai organisasi.

2. Kemauan untuk mengusahakan tercapainya kepentingan organisasi.

3. Keinginan yang kuat untuk mempertahankan keanggotaannya.

\section{Pembentukan Komitmen Organisasi}

Komitmen dalam berorganisasi dapat terbentuk adanya beberapa faktor, baik dari individu yaitu ( Parinding 2015)

1. Proses terbentuknya komitmen afektif

a. Karakteristik organisasi

b. Karakteristik individu

c. Pengalaman kerja

2. Proses terbentuknya komitmen berkelanjutan Menurut Umam (2012: 261) "beberapa tindakan atau kejadian ini dapat dibagi kedalam dua variabel, yaitu investasi dan alternatif. Selain itu, proses pertimbangan juga dapat mempengaruhi individu."

a. Investasi termasuk sesuatu yang berharga, seperti waktu, usaha, ataupun uang, yang harus dilepaskan karyawan jika meninggalkan organisasi.

b. Alternatif adalah kemungkinan untuk masuk ke organisasi lain 
3. Proses terbentuknya komitmen normatif

a. Tekanan Kerja yang mempengaruhi komitmen normatif terhadap organisasi dapat berkembang dari sejumlah tekanan yang dirasakan karyawan selama proses sosialisasi dan selama sosialisasi saat karyawan baru masuk ke dalam organisasi.

b. Penghargaan (Award) yang mempengaruhi komitmen normatif juga berkembang karena organisasi memberikan sesuatu yang sangat berharga bagi karyawan yang tidak dapat dibalas kembali.

c. Kontrak psikologis yang mempengaruhi komitmen normatif ini, bahwa diantara anggota dan organisasinya yaitu kepercayaan dari masing-masing pihak bahwa masing-masing akan timbal balik memberi.

\section{Kinerja}

Byars \& Rue (2008: 216), mengemukakan bahwa kinerja “...refers to the degree of accomplishment of the task that make up an employee's job. It reflects, how well an employee is fulfilling the requirements of the job". Dari pernyataan ini, bahwa kinerja mengacu pada tingkat pemenuhan tugas yang membentuk pekerjaan karyawan.

\section{Indikator Kinerja}

Byars \& Rue (2008), mempertegas bahwa kinerja merupakan hasil dari usaha karyawan yang dipengaruhi oleh kemampuan dan persepsi peran (tugas). Dengan demikian, dalam situasi tertentu kinerja dapat dilihat sebagai hasil dari hubungan antara usaha, kemampuan dan persepsi tugas. Berdasarkan pengertian kinerja tersebut maka Kinerja sangat dipengaruhi oleh beberapa faktor sebagai berikut: Effort (Usaha), Abilities (Kemampuan) dan Role/task perceptions (Persepsi peran/tugas)

\section{Penilaian kinerja}

Bangun (2012:231) mengungkapkan bahwa penilaian kinerja adalah proses yang dilakukan organisasi untuk mengevaluasi atau menilai keberhasilan karyawan dalam melaksanakan tugasnya. Penilaian dapat dilakukan dengan membandingkan hasil kerja yang dicapai karyawan dengan standar pekerjaan.Mulyadi (2015:113)

\section{Hubungan Komitmen Afektif dengan Kinerja}

Komitmen afektif merupakan seseorang yang memiliki keinginan emosional untuk tetap dalam satu organisasi karena mereka percaya terhadap misi yang dijalankan organisasi. Menurut Robbins (2008) bahwa komitmen afektif memiliki hubungan yang lebih erat dengan hasil organisasi seperti kinerja dan perputaran karyawan biladibandingkan dengan dua dimensi komitmen lain.

\section{Hubungan komitmen Berkelanjutan dengan Kinerja}

Menurut penelitian yangdilakukan oleh Nurandini (2014) mengatakan karyawan yang continuance commitmentnya tinggi akan berpengaruh signifikan terhadapkinerjanya karena dia merasa membutuhkan organisasi tersebut.

\section{Hubungan Komitmen Normatif dengan Kinerja}

Komitmen karyawan dihubungkan dengankepuasan kerja, tingkat absensi, dan kinerja karyawan (Sterrs) dalam Fuad Mas'ud(2004). Semakin tinggi komitmen maka akan semakin baik kinerja karyawan(Barbara, 1990) dalam Fuad Mas'ud (2004).

\section{Kerangka Pemikiran}

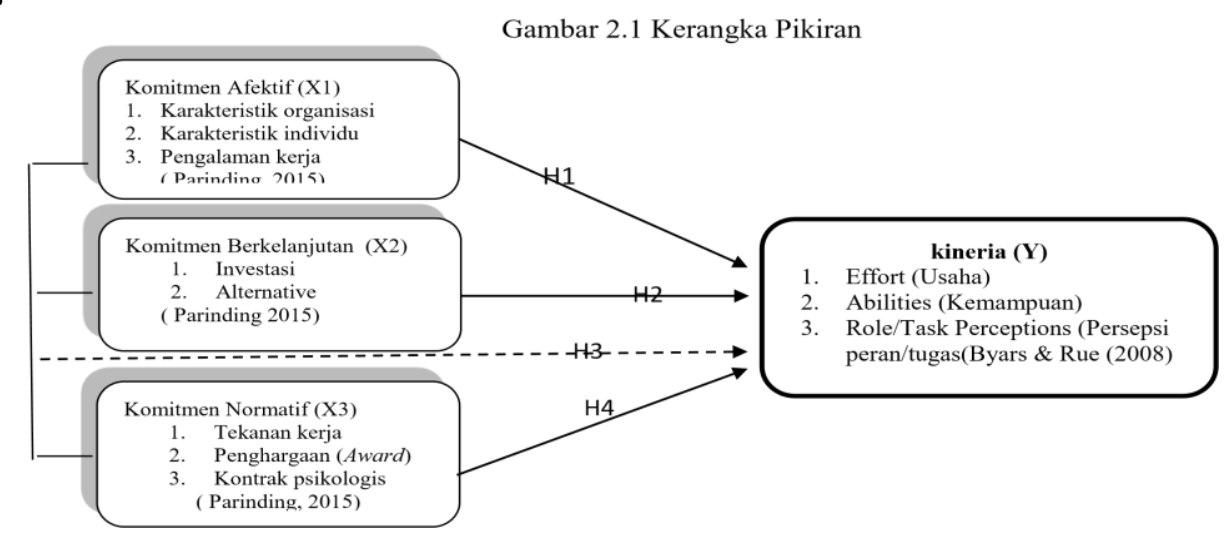




\section{Hipotesis}

Hipotesis merupakan jawaban sementara terhadap rumusan masalah penelitian, oleh karena itu rumusan masalah penelitian biasanya disusun dalam bentuk pernyataan.

Hipotesis dalam penelitian ini adalah :

1. Komitmen afektif, komitmen berkelanjutan, serta komitmen normatif secara bersama-sama berpengaruh signifikan terhadap kinerja karyawan pada PT Radio Nebula Nada Palu.

2. Komitmen afektif secara parsial berpengaruh signifikan terhadap kinerja karyawan pada PT Radio Nebula Nada Palu.

3. Komitmen berkelanjutan secara parsial berpengaruh signifikan terhadap kinerja karyawan pada PT Radio Nebula Nada Palu.

4. Komitmen normatif secara parsial berpengaruh signifikan terhadap kinerja karyawan pada PT Radio Nebula Nada Palu.

\section{METODE PENELITIAN}

\section{Jenis Penelitian}

Jenis penelitian ini adalah deskriptif kuantitatif. Penelitian deskriptif artinya memberikan pemaparan dalam bentuk interprestasi tentang pengaruh komitmen organisasi terhadap kinerjakaryawan Kantor PT Radio Nebula Nada Palu.

\section{Lokasi dan Objek Penelitian}

Penelitian ini dilakukan pada kantor PT Radio Nebula Nada palu yang berlokasi di jalan Rajawali no 28 Palu, Sulawesi Tengah. Objek penelitian dalam penelitian ini adalah Komitmen organisasi yang terdiri dari Afektif, kontinyu dan Normatif dan kinerja.

\section{Jenis data}

Jenis data yang digunakan dalam penelitian ini adalah:

1. Data Kualitatif

2. Data Kuantitatif

\section{Sumber Data}

1. Data Primer dalam penelitian data tentang karakteristik responden melalui variabel-variabel penelitian yang dinilai dapat meningkatkan kompetensi karyawan pada Kantor PT Radio Nebula Palu.

2. Data Sekunder dalam penelitian ini meliputi serajah singkat dan struktur organisasi, aspekaspek dan literatur kepustakaan lainnya.

\section{Populasi Penelitian}

Tabel 1 Populasi Penelitian

\begin{tabular}{|c|l|c|}
\hline No & \multicolumn{1}{|c|}{ Bidang } & Jumlah \\
\hline 1. & Komisaris Utama & 1 \\
\hline 2. & Direktur Utama & 1 \\
\hline 3. & Direktur Operasional & 1 \\
\hline 4. & Manajer Siaran & 2 \\
\hline 5. & Music Direktor & 2 \\
\hline 6. & Administrasi Keuangan & 1 \\
\hline 7. & Traffic & 1 \\
\hline 8. & Marketing & 2 \\
\hline 9 & OB & 2 \\
\hline 10 & Penyiar & 15 \\
\hline 11 & Security & 2 \\
\hline 12 & Koordinator Café & 31 \\
\hline & & \\
\hline
\end{tabular}


Sugiyono (2014:85), menyatakan bahwa sampling jenuh titik penentuan sampel bila semua anggota populasi digunakan sebagai sampel. Hal ini sering dilakukan bila jumlah populasi relatif kecil, kurang dari 30 orang, atau penelitian yang ingin membuat generalisasi dengan kesalahan yang sangat kecil.

\section{Metode Pengumpulan Data}

Dalam penelitian ini, teknik pengumpulan data yang dilakukan untuk mengukur variabel yang diteliti sebagai berikut:

1. Pengamatan/Observasi

2. Wawancara

3. Kuesioner

4. Dokumentasi

\section{Definisi Operasional Variabel}

Adapun variabel komitmen organisasi dalam penelitian ini terdiri dari variabel independent yaitu komitmen afektif (X1), komitmen berkelanjutan (X2), komitmen normatif (X3) dan variabel dependent atau tidak bebas (Y).

Tabel 2 Definisi Operasional Variabel

\begin{tabular}{|c|c|c|c|}
\hline Variabel & Dimensi & Indikator & $\begin{array}{c}\text { No } \\
\text { penyataan }\end{array}$ \\
\hline \multirow{3}{*}{$\begin{array}{l}\text { Komitmen Afektif (X1) } \\
\text { Komitmen afektif adalah } \\
\text { keyakinan yang kuat dari } \\
\text { karyawan terhadap } \\
\text { organisasi,menerima } \\
\text { tujuan organisasi serta } \\
\text { rela dalam upaya demi } \\
\text { kepentingan organisasi. } \\
\text { Sumber: Parinding, (2015) }\end{array}$} & $\begin{array}{c}\text { Karakteristik } \\
\text { organisasi }\end{array}$ & $\begin{array}{l}\text { 1. Pimpinan memperioritaskan } \\
\text { Kesejahteraan karyawan } \\
\text { 2. Mendalami pengetahuan dalam } \\
\text { peningkatan kinerja }\end{array}$ & $1-2$ \\
\hline & $\begin{array}{l}\text { Karakteristik } \\
\text { individu }\end{array}$ & 3. Kejujuran karyawan & 3 \\
\hline & $\begin{array}{l}\text { Pengalaman } \\
\text { kerja }\end{array}$ & 4. Kemahiran dalam berorganisasi & $4-5$ \\
\hline \multirow{2}{*}{\begin{tabular}{l} 
Komitmen \\
\multicolumn{1}{c}{ Berkelanjutan } \\
(X2) \\
Komitmen berkelanjutan \\
adalah karyawan akan \\
bertahan atau \\
meninggalkan organisasi \\
karena melihat \\
pertimbangan rasional \\
dari segi untung dan \\
ruginya. Sumber: \\
Parinding, (2015) \\
\end{tabular}} & Investasi & $\begin{array}{ll}\text { 5. } & \text { Ketepatan waktu kerja } \\
\text { 6. } & \text { Komitmen karyawan } \\
\text { 7. } & \text { Finansial } \\
\end{array}$ & $6-8$ \\
\hline & Alternatif & $\begin{array}{ll}\text { 8. } & \text { Fasilitas kerja } \\
9 . & \text { Lingkungan } \\
\text { kerja } & \end{array}$ & $9-10$ \\
\hline \multirow{3}{*}{$\begin{array}{l}\text { Komitmen Normatif } \\
\text { (X3) Komitmen normatif } \\
\text { adalah karyawan } \\
\text { memiliki rasa kewajiban } \\
\text { dan tanggung jawab } \\
\text { untuk tetap bertahan atau } \\
\text { tinggal dalam organisasi } \\
\text { Sumber: Parinding, } \\
\text { (2015) }\end{array}$} & Tekanan kerja & 10. Aturan perusahaan & $11-12$ \\
\hline & $\begin{array}{l}\text { Penghargaan } \\
\text { (award) }\end{array}$ & 11. Bonus terhadap pegawai & $13-14$ \\
\hline & $\begin{array}{l}\text { Kontrak } \\
\text { psikologis }\end{array}$ & $\begin{array}{l}\text { 12. Kepercayaan terhadap masingmasing } \\
\text { karyawan }\end{array}$ & $15-16$ \\
\hline
\end{tabular}


Patham, D.R.

\begin{tabular}{|c|c|c|c|}
\hline $\begin{array}{l}\text { Kinerja }(\mathrm{Y}) \\
\text { Kinerja adalah hasil dari } \\
\text { usaha karyawan yang } \\
\text { dipengaruhi oleh } \\
\text { kemampuan dan presepsi } \\
\text { peran (tugas) }\end{array}$ & Usaha (Effort) & $\begin{array}{ll}\text { 1. } & \text { Menyelesaikan tugas dengan baik } \\
\text { 2. } & \text { Bekerja dengan hati-hati, semangat } \\
\text { yang tinggi } \\
\text { 3. } & \begin{array}{l}\text { Memiliki kesungguhan dalam } \\
\text { melaksanakan tugas }\end{array} \\
\text { 4. } & \begin{array}{l}\text { Bekerjasama sebagai anggota } \\
\text { kelompok }\end{array}\end{array}$ & $17-21$ \\
\hline \multirow[t]{3}{*}{$\begin{array}{l}\text { Sumber : Byars dan Rue, } \\
\text { (2008) }\end{array}$} & & $\begin{array}{l}\text { 5. Bekerja sesuai batas waktu dan jadwal } \\
\text { yang telah ditentukan }\end{array}$ & \\
\hline & $\begin{array}{l}\text { Kemampuan } \\
\text { (Abilities) }\end{array}$ & $\begin{array}{ll}\text { 6. } & \text { Bekerja jauh dari kesalahan } \\
\text { 7. } & \text { Mengerjakan pekerjaan sesuai standar } \\
& \text { yang diinginkan } \\
\text { 8. } & \text { Menyelesaikan tugas sesuai dengan } \\
& \text { harapan } \\
\text { 9. } & \text { Cakap dalam melaksanakan tugas } \\
\text { 10. } & \text { Meguasai bidang pekerjaan dengan } \\
\text { baik }\end{array}$ & $22-26$ \\
\hline & $\begin{array}{c}\text { Persepsi } \\
\text { peran/tugas } \\
\text { (Role/task } \\
\text { perceptions) }\end{array}$ & $\begin{array}{l}\text { 11. Melaporkan hasil pekerjaan } \\
\text { 12. Melakukan tugas berdasarkan } \\
\text { pengetahuan } \\
\text { 13. Mempertimbangkan dan menerima } \\
\text { usul orang lain } \\
\text { 14. Mengutamakan kepentingan umum di } \\
\text { tempat kerja } \\
\text { 15. Selalu tegas dalam bertindak }\end{array}$ & $27-31$ \\
\hline
\end{tabular}

\section{Analisis Data}

Analisis data menggunakan regresi berganda adalah alat untuk meramalkan nilai pengaruh dua variabel bebas atau lebih terhadap satu variabel terikat (untuk membuktikan ada tidaknya hubungan fungsional atau hubungan kausal antara dua atau lebih variabel bebas terhadap suatu variabel Y) (Muhidin dan Aburahman, 2007 : 198).

\section{Uji Hipotesis}

Uji F (Simultan)

Uji F digunakan dengan membandingkan $\mathrm{p}$ (probability) dengan $\alpha=5 \%$. Formula Uji F sebagai berikut :

$$
\mathrm{F}_{0}=\frac{R^{2} /(K-1)}{1-R^{2} /(n-k)} \quad \text { Dimana : }
$$

F_(0 ) : Diperoleh dari tabel distribusi F

$$
\begin{array}{cr}
\mathrm{R}^{\wedge} 2 & : \text { Koefisien determinasi } \\
\mathrm{K} & : \text { Jumlah Variabel } \\
\mathrm{N} & : \text { Jumlah Sampel }
\end{array}
$$

\section{Uji t (Parsial)}

Uji t diformulasikan sebagai berikut :

$$
\boldsymbol{t}=\frac{\boldsymbol{\beta} \boldsymbol{i}}{\boldsymbol{s e}(\boldsymbol{\beta} \boldsymbol{i})} \text { Dimana : }
$$

$$
\begin{array}{ll}
\mathrm{t} & : \text { diperoleh dari daftar tabel } \mathrm{t} \\
\beta \mathrm{i} & : \text { parameter estimasi } \\
\mathrm{Se}(\mathrm{i}) & : \text { standar error }
\end{array}
$$

\section{Uji Determinasi ( $\left.R^{\wedge} 2\right)$}

Kemampuan variabel independen menerangkan variabel dependen dapat diketahui dari besarnya koefisien determinasi $\left(\mathrm{R}^{\wedge} 2\right)$. Jadi, $\mathrm{R}^{\wedge} 2$ digunakan untuk mengukur besarnya sumbangan secara 
simultan dari variabel-variabel independen yang diteliti terhadap variabel dependen. Jika $\mathrm{R}^{\wedge} 2$ semakin mendekati 1 (satu), maka sumbangan variable independen secara simultan terhadap variabel dependen semakin besar. Sebaliknya, jika $\mathrm{R}^{\wedge} 2$ semakin mendakati 0 (nol), maka variabel independen semakin lemah pengaruhnya dalam menjelaskan variabel dependen.

\section{HASIL DAN PEMBAHASAN \\ Hasil Pengujian Instrument Penelitian \\ Hasil Uji Validitas}

Suatu skala pengukuran dikatakan valid bila terdapat kesamaan antara data yang terkumpul dengan data yang sesungguhnya terjadi pada objek penelitian. Selanjutnya, valid berarti instrumen tersebut dapat digunakan untuk mengukur apa yang seharusnya diukur Sugiyono (2010:172).

\section{Komitmen afektif (X1)}

Berdasarkan hasil uji validitas yang telah dilakukan, diketahui bahwa 5 item pernyataan yang dinyatakan valid pada variabel komitmen afektif (X1). Hasil uji validitas dapat dilihat pada Tabel 3 berikut ini:

Tabel 3 Hasil Pengujian Validitas Variabel komitmen afektif (X1)

\begin{tabular}{|c|c|c|c|}
\hline Item penyataan & r- hitung & r-kritis & Status \\
\hline 1 & $\mathbf{0 , 9 2 3}$ & $\mathbf{0 , 3 5 5}$ & Valid \\
\hline 2 & $\mathbf{0 , 5 0 2}$ & $\mathbf{0 , 3 5 5}$ & Valid \\
\hline 3 & $\mathbf{0 , 4 7 6}$ & $\mathbf{0 , 3 5 5}$ & Valid \\
\hline 4 & $\mathbf{0 , 9 5 6}$ & $\mathbf{0 , 3 5 5}$ & Valid \\
\hline 5 & $\mathbf{0 , 9 5 6}$ & $\mathbf{0 , 3 5 5}$ & Valid \\
\hline
\end{tabular}

Sumber: Data Yang Diolah Melalui SPSS 22

\section{Komitmen Berkelanjutan}

Hasil uji validitas dapat dilihat pada Tabel berikut ini:

Tabel 4 Hasil Uji Validitas Variabel komitmen berkelanjutan (X2)

\begin{tabular}{|c|c|c|c|}
\hline Item peryataan & r-hitung & r-kritis & Status \\
\hline 1 & 0,979 & 0,355 & Valid \\
\hline 2 & 0,531 & 0,355 & Valid \\
\hline 3 & 0,979 & 0,355 & Valid \\
\hline 4 & 0,979 & 0,355 & Valid \\
\hline 5 & 0,979 & 0,355 & Valid \\
\hline
\end{tabular}

Sumber:Data Yang Diolah Melalui SPSS 22

Berdasarkan hasil uji validitas diketahui bahwa dari 5 item pernyataan yang dinyatakan valid pada Komitmen Berkelanjutan (X2).

\section{Komitmen Normatif}

Hasil uji validitas dapat dilihat pada tabel berikut ini:

Tabel 5 Hasil Uji Validitas Variabel Komitmen Normatif (X3)

\begin{tabular}{|c|c|c|c|}
\hline Item Penyataan & R-Hitung & R-Krisis & Status \\
\hline 1 & 0,877 & 0,355 & Valid \\
\hline 2 & 0,599 & 0,355 & Valid \\
\hline 3 & 0,397 & 0,355 & Valid \\
\hline 4 & 0,770 & 0,355 & Valid \\
\hline 5 & 0,770 & 0,355 & Valid \\
\hline 6 & 0,381 & 0,355 & Valid \\
\hline
\end{tabular}

Sumber: Data Yang Diolah Melalui SPSS 22 
Berdasarkan hasil uji validitas diketahui bahwa dari 6 item pernyataan yang dinyatakan valid pada Komitmen Normatif (X3).

\section{Kinerja (Y)}

Hasil uji validitas dapat dilihat pada tabel berikut ini:

Tabel 6 Hasil Pengujian Validitas Variabel Kinerja (Y)

\begin{tabular}{|c|c|c|c|}
\hline Item peryataan & r-hitung & r-krisis & Status \\
\hline 1 & 0,967 & 0,355 & Valid \\
\hline 2 & 0,967 & 0,355 & Valid \\
\hline 3 & 0,967 & 0,355 & Valid \\
\hline 4 & 0,960 & 0,355 & Valid \\
\hline 5 & 0,960 & 0,355 & Valid \\
\hline 6 & 0,960 & 0,355 & Valid \\
\hline 7 & 0,967 & 0,355 & Valid \\
\hline 8 & 0,960 & 0,355 & Valid \\
\hline 9 & 0,663 & 0,355 & Valid \\
\hline 10 & 0,960 & 0,355 & Valid \\
\hline 11 & 0,967 & 0,355 & Valid \\
\hline 12 & 0,663 & 0,355 & Valid \\
\hline 13 & 0,663 & 0,355 & Valid \\
\hline 14 & 0,960 & 0,355 & Valid \\
\hline 15 & 0,960 & 0,355 & Valid \\
\hline
\end{tabular}

Sumber: Data Yang Diolah Melalui SPSS 22

Berdasarkan hasil uji validitas yang telah dilakukan diketahui bahwa semua item pernyataan untuk kinerja $(\mathrm{Y})$ dalam kuesioner yang digunakan pada penelitian ini adalah valid. 15 item pernyataan layak (sahih) diikutsertakan dalam penelitian ini, karena koefisien korelasi (r-hitung) yang diperoleh lebih besar dari 0,355 atau lebih besar dari nilai r-krits (Sugiyono :179).

\section{Hasil Uji Regresi Linear Berganda}

Berkaitan dengan penelitian ini, alat analisis statistik Parametrik Regresi Linear Berganda digunakan untuk mengukur pengaruh dari variabel komitmen afektif, komitmen berkelanjutan dan komitmen normatif terhadap kinerja.

Tabel 7 Hasil Uji Regresi Linear Berganda

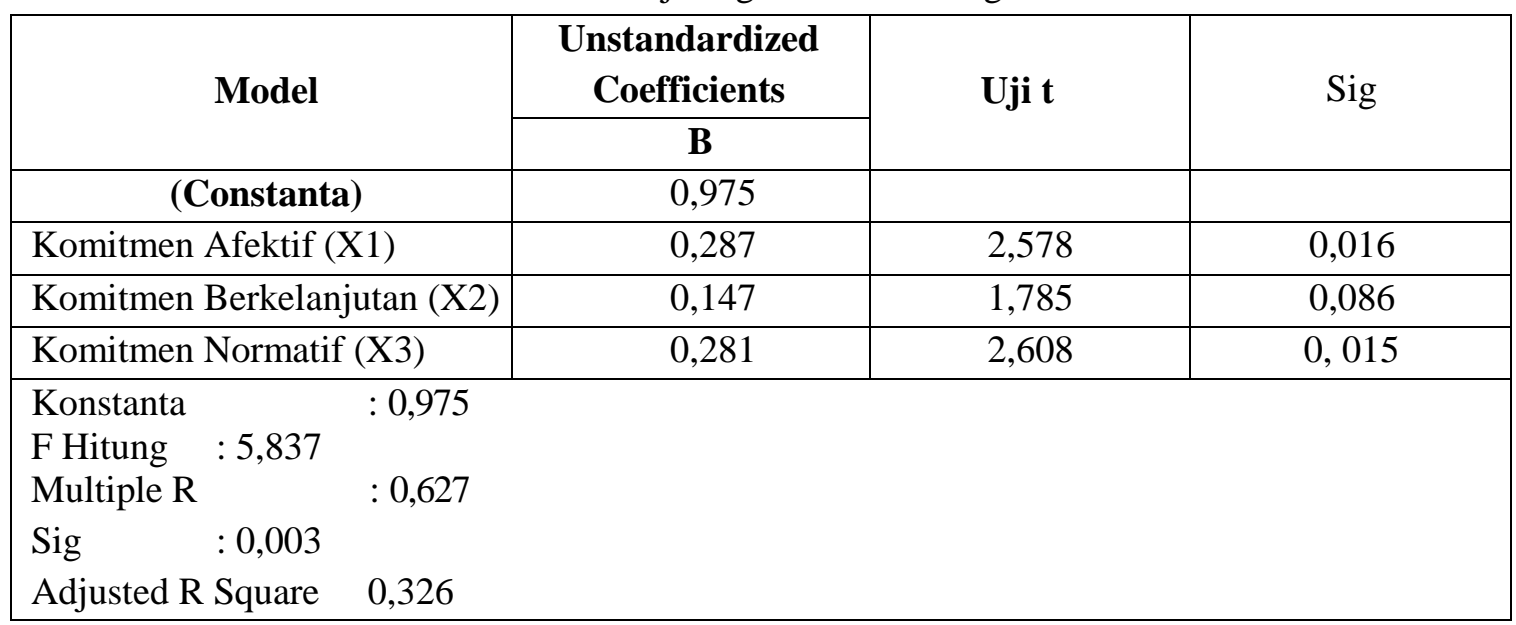

$Y=0,975+0,287 \aleph_{1}+0,147 \aleph_{2}+0,281 \aleph_{3}$ 
Interprestasi dari persamaan tersebut adalah sebagai berikut :

1. Nilai konstanta $(\alpha)$ memiliki nilai 0,975 , hal ini berarti jika variabel $\mathrm{X} 1, \mathrm{X} 2, \mathrm{X} 3$ bernilai 0 maka kinerja karyawan PT Radio Nebula Nada di Kota Palu memiliki nilai tetap positif 0,975.

2. Nilai koefisien regresi variabel Komitmen afektif (X1) adalah positif yaitu sebesar 0,287. Dengan tingkat signifikansi sebesar $0,016<0,05$ Hal ini menyatakan bahwa jika variabel komitmen afektif ditingkatkan, maka akan mengakibatkan kinerja karyawan sebesar 0,287 dengan asumsi variabel lain konstan.

3. Nilai koefisien regresi variabel komitmen berkelanjutan (X2) adalah positif yaitu sebesar 0,147 dengan tingkat signifikansi sebesar 0,086 >0,05 menunjukan bahwa variabel komitmen berkelanjutan tidak memiliki pengaruh nyata atau signifikan dengan peningkatan kinerja karyawan 0,147, dengan asumsi variabel lain konstan.

4. Nilai koefisien regresi variabel komitmen normatif (X3) adalah positif yaitu sebesar 0,281 dengan tingkat signifikansi sebesar $0,015<0,05$ menujukkan bahwa variabel komitmen normatif (X3) ditingkatkan, maka akan mengakibatkan peningkatkan kinerja karyawan sebesar 0,281 dengan asumsi variabel lain konstan.

5. Nilai koefisien korelasi (Multiple R) yaitu sebesar 0,627 . Nilai $\mathrm{R}$ berkisar antara 0 sampai 1 , apabila nilai $\mathrm{R}$ mendekati 0 maka hubungan antara variabel semakin rendah. Apabila nilai $\mathrm{R}$ mendekati 1 maka hubungan antara variabel semakin tinggi. Nilai pada penelitian ini adalah 0,627 menunjukkan bahwa hubungan antara komitmen afektif, komitmen berkelanjutan, dan komitmen normatif terhadap kinerja karyawan adalah mendekati tinggi.

\section{Hasil Pengujian Hipotesis Uji}

\section{Simultan (Uji F)}

Berdasarkan hasil uji ANOVA (Analysis of Varians) atau F test diperoleh nilai F_(hitung ) sebesar 5.837 signifikansi lebih kecil dari taraf nyata $5 \%(0,000<0,05)$. Dengan demikian (Ho) ditolak dan (Ha) diterima, karena terdapat pengaruh antara variabel $\mathrm{X}$ (komitmen afektif, komitmen berkelanjutan dan komitmen normatif) secara simultan terhadap variabel Y (kinerja).

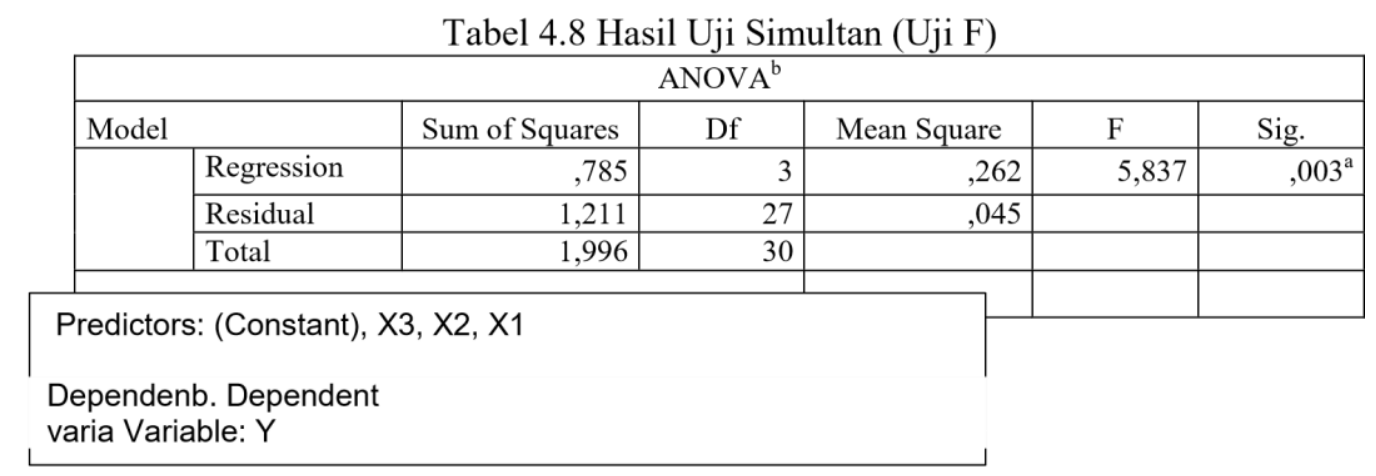

\section{Sumber : Hasil Analisis (Lampiran 4)}

Berdasarkan hasil uji parsial diketahui seberapa jauh pengaruh satu variabel independen secara individual dalam menerangkan variasi variabel dependen yaitu :

\section{Variabel Komitmen Afektif (X1)}

Dari hasil pengolahan data yang dilakukan, dapat dilihat besar probabilitas signifikan komitmen afektif (X1) sebesar $0,016<\alpha 0,05$ maka secara statistik dalam penelitian ini variabel komitmen afektif berpengaruh nyata (signifikan) terhadap variabel kinerja karyawan di PT Radio Nebula Nada di Kota Palu.

\section{Variabel Komitmen Berkelanjutan (X2)}

Berdasarkan hasil pengolahan data yang dilakukan, dapat dilihat besar probabilitas signifikan komitmen Berkelanjutan $\left(\mathrm{X}_{2}\right)$ sebesar 0,086> $\alpha 0,05$.

\section{Variabel Komitmen Normatif (X3)}

Berdasarkan hasil pengolahan data yang dilakukan, dapat dilihat besar probabilitas signifikan komitmen normatif (X3) sebesar $0,015<\alpha 0,05$ 
Patham, D.R.

Tabel 9 Hasil Uji Parsial (Uji t)

\begin{tabular}{|c|c|c|c|c|c|c|}
\hline \multicolumn{7}{|c|}{ Coefficients $^{\mathbf{a}}$} \\
\hline \multirow{2}{*}{\multicolumn{2}{|c|}{ Model }} & \multicolumn{2}{|c|}{ Unstandardized Coefficients } & \multirow{2}{*}{$\frac{\text { Standardized Coefficients }}{\text { Beta }}$} & \multirow[b]{2}{*}{$\mathrm{t}$} & \multirow[b]{2}{*}{ Sig. } \\
\hline & & B & Std. Error & & & \\
\hline \multirow[t]{4}{*}{1} & (Constant) & ,975 & ,684 & & 1,424 & , 166 \\
\hline & $\mathrm{X} 1$ & 287 & ,111 & ,387 & 2,578 & ,016 \\
\hline & $\mathrm{X} 2$ & ,147 &, 082 & ,268 & 1,785 & ,086 \\
\hline & X3 & 281 & , 108 & ,392 & 2,608 & ,015 \\
\hline \multicolumn{3}{|c|}{ a. Dependent Variable: Y } & & & & \\
\hline
\end{tabular}

\section{Uji Determinasi}

Agar dapat mengetahui seberapa besar kontribusi variabel independen (komitmen afektif, komitmen berkelanjutan dan komitmen normatif) terhadap variabel dependen (kinerja) digunakan nilai dari hasi uji R2. Hasil uji R dijelaskan sebagai berikut.

Tabel 10 Koefisien Determinasi

\begin{tabular}{|l|rr|r|r|r|}
\hline \multicolumn{1}{|c|}{ Model } & R & & R Square & Adjusted R Square & $\begin{array}{c}\text { Std. Error of the } \\
\text { Estimate }\end{array}$ \\
1 & & 0.627 & 0.393 & 0.326 & 0.21176 \\
\hline
\end{tabular}

Dari hasil pengolahan data yang dilakukan dengan menggunakan SPSS diatas, dapat dilihat bahwa nilai $\mathrm{R}$ dan $\mathrm{R}$ square masing-masing 0,627 dan 0,393 dijelaskan sebagai berikut.

1. R square (R2) atau koefisien determinasi memiliki nilai sebesar 0,393. Artinya, semua variabel independen (komitmen afektif, komitmen berkelanjutan dan komitmen normatif) jika terjadi perubahan 1 satuan maka variabel dependen (kinerja operasional) mengalami perubahan sebesar 0,393 atau sebesar 39,3\% dan sisanya 60,7\% dipengaruhi oleh faktor lain yang tidak dimasukkan dalam penelitian ini.

2. Selain R2 ada juga koefisien korelasi (R) dengan nilai sebesar 0,627 yang berarti bahwa variabel yang diteliti yaitu komitmen afektif, komitmen berkelanjutan dan komitmen normatif mempunyai hubungan yang kuat dengan variabel terikatnya sebesar 0,627 atau sebesar $62 \%$.

\section{Pembahasan Hasil Penelitian}

\section{Pengaruh Komitmen Afektif, komitmen Berkelanjutan dan komitmen Normatif Secara Simultan Terhadap Kinerja (Y).}

Dari hasil penelitian diketahui bahwa secara simultan komitmen organisasi berpengaruh signifikan terhadap kinerja, hal ini membuktikan dari hasil penelitian berdasarkan tabel 5.16 di ketahui besarnya F hitung 5,835 pada signifikansi probabilitas 0,003 menunjukan bahwa terdapat pengaruh yang signifikan variabel komitmen afektif, komitmen berkelanjutan, dan komitmen normative terhadap kinerja karyawan pada PT Radio Nebula Nada di Kota Palu. Dalam Analisis pengaruh komitmen afektif, komitmen berkelanjutan dan komitmen normative terhadap kinerja karyawan PT Pegadaian (Persero) Cabang Ketapangoleh Parinding Roberto Goga (2015) menyatakan bahwa terdapat berpengaruh positif antara kinerja karyawan (Komitmen Afektif, komitmen Berkelanjutan dan komitmen Normatif).

\section{Pengaruh komitmen afektif terhadap Kinerja.}

Berdasarkan hasil penelitian ini melalui pengamatan maupun penyebaran kuisioner karyawan PT Radio Nebula Nada di Kota Palu memiliki keinginan setiap karyawan sangat besar untuk bekerja sehingga mengakibatkan hasil kinerja yang mereka lakukan sesuai dengan tujuan perusahaan.

Menurut Parinding Roberto Goga, (2015)Ada pengaruh yang positif dan signifikan antara komitmen afektif terhadap kinerja menunjukan kuatnya keinginan emosional karyawan untuk beradaptasi dengan nilai-nilai yang ada agar tujuan dan keinginannya untuk tetap di organisasi dapat terwujud.

Hasil analisis ini mendukung argumen yang disajikan dalam Kaswan(2012: 293) Komitmen afektif dapat timbul pada diri seorang karyawan di karenakan adanya karakteristik individu, karakteristik struktur organisasi, signfikansi tugas, berbagai keahlian, umpan balik dari pemimpin, dan keterlibatan 
dalam manajemen. "umur dan lama masa kerja di perusahaan sangat berhubungan positif dengan komitmen afektif.

\section{Pengaruh Komitmen Berkelanjutan terhadap Kinerja}

Dari hasil uji parsial (uji t), diketahui menunjukan signifikansi variabel komitmen berkelanjutan sebesar 0,086. Nilai signifikasi lebih besar dari tingkat signifikansi yang ditetapkan peneliti $(0,086>$ 0,05). Dari hasil pengamatan peneliti bahwa adanya karyawan tidak muda lagi (berumur) yang sudah jenuh untuk berpikir, tidak semangat lagi bekerja serta membuat mereka berpikir untuk apa melakukan kinerja yang bagus atau berkualitas dalam kinerja dan di sebabkan menika atau tuntutan pekerjaan suami sehingga terjadi pengunduran diri (Resign)Jadi, di simpulkan pengaruh variabel komitmen berkelanjutan, menunjukan hasil yang tidak berpengaruh signifikan terhadap kinerja karyawan.

Dalam hasil analisis ini, ditemukan bahwa komitmen berkelanjutan menunjukan hasil yang tidak signifikan terhadap kinerja karyawan.Penelitian ini sejalan dengan penelitian yang dilakukan Parinding Roberto Goga (2015), hasil penelitian dari jurnal ini menyebutkan bahwa ketiga jenis komitmen afektif, komitmen berkelanjutan dan komitmen normatif memiliki pengaruh signifikan terhadap kinerja karyawan. Namun pada komitmen berkelanjutan masih ada karyawan kurang setuju bahkan tidak setuju dengan komitmen yang ada. Sebaliknya penelitian yang dilakukan Yetta Tri Nydia (2012) tidak sejalan dengan hasil penelitian ini yaitu hasil dari jurnal ini menjelaskan bahwan komitmen berkelanjutan berpengaruh signifikan dan nyata terhadap kinerja karyawan, serta memiliki pengaruh yang paling besar dari variabel-variabel yang mempengaruhi kinerja karyawan.

\section{Pengaruh komitmen Normatif Terhadap Kinerja}

Berdasarkan hasil observasi penulis menyusun penelitian darikomitmen normatif dari hasil analisis uji parsial (uji t) di ketahui mempunyai hubungan positif yang signifikan terhadap kinerja karyawan PT Radio Nebula Nada di Kota Palu.

Besarnya F_(hitung ) sebesar 5,837 pada signifikansi probabilitas 0,015. Sesuai dengan ketentuan, apabila nilai yang diperoleh berada di bawah 0,05 maka pengaruh variabel independen X3 yaitu komitmen normatifterhadap variabel dependen Y yaitu Kinerja, dikatakan sangat kuat (signifikan).

Hasil panelitian ini didukung oleh penelitian terdahulu yang dilakukan Parinding (2015) yang menyatakan bahwa variabel komitmen normative berpengaruh positif terhadap kinerja karyawan.Pembuktian hasil penelitian yang dilakukan Yetta Tri Nydia (2012) menyatakan komitmen normative tidak berpengaruh terhadap kinerja.

\section{KESIMPULAN DAN SARAN}

\section{Kesimpulan}

Berdasarkan hasil dan pembahasan yang telah dilakukan pada bab sebelumnya, dapat diambil kesimpulan sebagai berikut :

1. Komitmen Organisasi yang terdiri dari komitmen afektif (X1), komitmen Berkelanjutan (X2), dan komitmen normatif (X3) secara simultan berpengaruh signifikan terhadap kinerja karyawan pada PT Radio Nebula Nada di Kota Palu.

2. Variabel komitmen afektif (X1) dan berpengaruh positif dan signifikan terhadap kinerja karyawan PT Radio Nebula Nada di Kota Palu.

3. Variabel komitmen berkelanjutan (X2) berpengaruh positif dan tidak signifikan terhadap kinerja karyawanPT Radio Nebula Nada di Kota Palu.

4. Variabel komitmen normatif (X3) berpengaruh signifikan terhadap kinerja karyawanPT Radio Nebula Nada di Kota Palu.

\section{Saran}

Berdasarkan pembahasan dan kesimpulan yang ada, saran-saran yang dapat diberikan penulis adalah sebagai berikut :

1. Bagi pimpinan serta bawahan karyawan PT Radio Nebula Nada di kota Palu hendaknya mempertahankan komitmen afektif yang mana melihat dari keinginan emosional dalam bekerja yang muncul dari setiap individu karyawan agar sesuai kemampuan serta bakat yang mereka miliki, 
2. Pimpinan PT Radio Nebula Nada Palu hendak lebih meningkatkan komitmen berkelanjutan, karyawan keluar (resign) karena mengikuti suami yang bertugas diluar Kota Palu dan dari hasil penelitian ternyata berpenngaruh positif dan tidak signifikan terhadap kinerja karyawan,.

3. Setiap karyawan hendaknya lebih meningkatkan kedisiplinan masalah ketepatan waktu dalam menyelesaikan tugas terhadap komitmen normatif.

4. Untuk penelitian selanjutnya, diharapkan dapat menambah variabel penelitian yang dapat mempengaruhi kinerja karyawan PT Radio Nebula Nada di Kota Palu, agar hasil penelitiannya dapat memberikan kontribusi yang lebih untuk pihak-pihak yang bersangkutan.

\section{REFERENSI}

Bangun Wilson, (2012). Manajemen Sumber Daya Manusia. Penerbit Erlangga

Byars, Lloyd L. dan Leslie W. Rue, (2008). Human Resources Management. Ninth Edition, Mc GrawHill Companies, New York Fuad Mas'ud (2004). Survai Diagnosis Organisasional (Konsep dan Aplikasi), Badan Penerbit Universitas Diponegoro

Kaswan (2012). Manajemen sumber daya manusia untuk keunggulan erasing organisasi. Cetakan pertama. Yogyakarta: Graha Ilmu

Muhidin, Sambas Ali dan Marwan Abdurrahman, (2007). Analisis Korelasi Regresi Dan Jalur Dalam Penelitian. CV. Pustaka Setia, Bandung.

Mulyadi, (2015). Manajemen Sumber Daya Manusia. Bogor: In Media

Nurandini, Arina (2014). Analisis Pengaruh Komitmen Organisasi terhadap kinerja karyawan (Studi pada Pegawai Perum Perumnas Jakarta, Jurnal Ilmu Manajemen Hal 1-20

Nydia, Yetta Tri (2012). Pengaruh Komitmen Organisasional terhadap kinerja karyawan lapangan SPBU coco pertamina MT Haryono. program sarjana ekstensi depok.

Parinding,, Roberto Goga (2015). Analisis Pengaruh Komitmen afektif, Komitmen Berkelanjutan, Dan Komitmen Normatif Terhadap Kinerja Karyawan Pada PT. Pengadaian (Persero) Cabang Ketapang. E.Jurnal Ilmu Manajemen Magistra Vol.1 No.2 Hal 1-37

Santoso Singgih, (2002). Statistik Dengan SPSS. Media Komputindo, Jakarta

Sopiah, (2008). Perilaku Organisasional. Penerbit Andi.Malang

Stephen P. Robbins \& Timothy A. Judge, (2008). Perilaku Organisasi, Jakarta: Indeks Kelompok Gramedia.

Sugiyono, (2009). Metodologi Penelitian Bisnis. Alfabeta, Bandung

Sugiyono, (2014). Metode Penelitian Kuantitatif, Kualitatif dan R\&D. Edisi, Alfabeta, Badung

Umam, Khaerul (2012). Perilaku organisasi, cetakan kedua. Bandung: Pustaka setia Umar,

Husein, 2002). Metode Riset Bisnis. Gramedia Pustaka Utama, Jakarta. 